This article was downloaded by: [Hania Nashef]

On: 16 December 2011, At: 21:44

Publisher: Routledge

Informa Ltd Registered in England and Wales Registered Number: 1072954 Registered

office: Mortimer House, 37-41 Mortimer Street, London W1T 3J H, UK

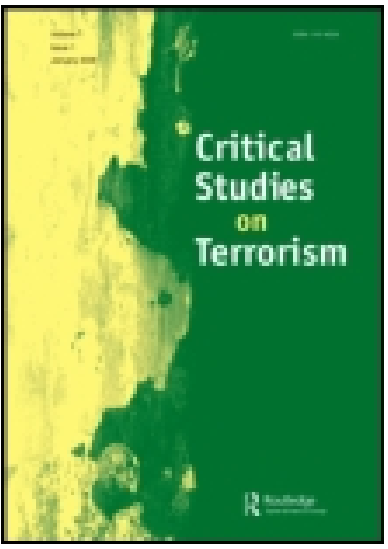

\title{
Critical Studies on Terrorism
}

Publication details, including instructions for authors and subscription information:

http:// www.tandfonline.com/loi/ rter20

\section{The blurring of boundaries: images of abjection as the terrorist and the reel Arab intersect}

\author{
Hania A.M. Nashef ${ }^{a}$ \\ ${ }^{a}$ Department of Mass Communication, American University of \\ Sharjah, Sharjah, United Arab Emirates \\ Available online: 16 Dec 2011
}

To cite this article: Hania A. M. Nashef (2011): The blurring of boundaries: images of abjection as the terrorist and the reel Arab intersect, Critical Studies on Terrorism, 4:3, 351-368

To link to this article: http:// dx.doi.org/ 10.1080/ 17539153.2011.623403

\section{PLEASE SCROLL DOWN FOR ARTICLE}

Full terms and conditions of use: http://www.tandfonline.com/page/terms-andconditions

This article may be used for research, teaching, and private study purposes. Any substantial or systematic reproduction, redistribution, reselling, loan, sub-licensing, systematic supply, or distribution in any form to anyone is expressly forbidden.

The publisher does not give any warranty express or implied or make any representation that the contents will be complete or accurate or up to date. The accuracy of any instructions, formulae, and drug doses should be independently verified with primary sources. The publisher shall not be liable for any loss, actions, claims, proceedings, demand, or costs or damages whatsoever or howsoever caused arising directly or indirectly in connection with or arising out of the use of this material. 


\title{
ARTICLE \\ The blurring of boundaries: images of abjection as the terrorist and the reel Arab intersect
}

\author{
Hania A.M. Nashef* \\ Department of Mass Communication, American University of Sharjah, Sharjah, United Arab \\ Emirates
}

(Received 9 April 2011; final version received 28 August 2011)

\begin{abstract}
In her treatise on abjection, Julia Kristeva argues that the abject is located outside the self, remaining in a state of repulsion that threatens to destroy the self. Abject representations are prevalent in the way terrorists have been portrayed in the Western news media post-September 11, 2001. These images of abjection are problematic, as they consolidate the images we have seen in Hollywood films representing Arabs. Furthermore, these depictions have eroded the fine line between the real and the unreal. This article examines the point at which these issues intersect, by analysing individual images vis-à-vis film portrayals of the Arab and, ultimately, how the framed images of terrorists aired on TV screens have conformed to previously accepted notions of the Arab.
\end{abstract}

Keywords: abjection; terrorism; image; media; dehumanisation

\section{Introduction: the abject and the other}

Julia Kristeva (1982, p. 1) argues that the abject always lies outside the self and its one link to the self resides in being its opposite. Furthermore, it is immoral, sinister [and] scheming (Kristeva 1982, p. 4). Even though abjection is located outside the self, it nonetheless remains in a state of repulsion that threatens to destroy the self as the meaning becomes blurred between the subject and that other, ultimately breaking down. The abject is the other that is always irrational, suspect and alien, the propagator of phobia. Abject representations of alleged or convicted terrorists have been prevalent throughout the Western media post-September 11, 2001. Not only are these images of abjection abhorrent, but they are also problematic as they consolidate the images we have seen on numerous occasions in Hollywood films representing the Arabs. In such portrayals, Arabs are lumped together as one entity, and as Lina Khatib (2006, p. 6) observes, Arabs are not assigned a particular nationality or even a particular Arabic accent or dialect, assuming that they are actually speaking Arabic and not some guttural gibberish supposedly sounding like Arabic.

In some respect, the post-September 11 image of the Arab/Moslem terrorist had to fit in the mould that had previously been defined by film. Mirroring the reel image obscures the boundaries that have existed between the real and the unreal. ${ }^{1} \mathrm{~A}$ lot of framing is

*Email: hnashef@eim.ae 
at play, and it becomes unclear as to what came first, the image or the real person, or, in Baudrillardian terms, at best a simulated version of the real (Baudrillard 2004). A metathesis of sorts occurs, and the more these terrorist images are aired the stronger the link. I propose that the depictions of the real terrorists have been at once successful in eroding the fine lines between the real and the unreal and in exasperating an already fragile condition which builds on a repertoire of the ugly Arab in Western media. This site of representation, which I suggest is located in the abject, a priori allows the Arab to be perceived as other and essentially not human.

In this article, I will examine the reason for these abject representations and argue that these images - whether reel or real - are at once possible projections from the abject and/or an insecurity resulting from a lack within and an illogical fear of the other. I will also discuss the point at which these issues intersect by analysing a number of individual images of real terrorists as aired on TV newscasts around the world, vis-à-vis earlier film portrayals of the Arab. I hope to demonstrate how these images have not only conformed to the previously accepted notions set by film, but also authenticated the stereotype presented by the image as real. Although there are a number of studies which have explored the image of the Hollywood Arab, this article, which examines the latter vis-à-vis real terrorist images and discusses the negative impact of the breaking down of boundaries between the real and the reel, will not only add to the existing scholarship but also explain the implications of this blurring. I will also demonstrate how the long history of dehumanising the Arabs in film has paved the way for the choice of the terrorists' images which have been aired ad nauseam on television screens.

I begin with a brief historical discussion on how this image came about and its effect on Arab and non-Arab alike, drawing on postcolonial and postmodern theories as well as whiteness studies, before analysing the dangers of blurring that have taken place following the emergence of the real terrorists. I will also draw on Baudrillard's concept of simulation to demonstrate how this blurring occurs and on Kristeva's theory of abjection to explain what propels the individual to project what is repulsive within the self onto an external other.

\section{Terrorism as the only site for the Arab in film: a historical perspective}

Before discussing the consequences of such presentations, I would like to refer to some detailed studies on the image of the Arab in American cinema. Jack G. Shaheen has documented Hollywood misrepresentations of Arabs in Reel Bad Arabs and Guilty: Hollywood's Verdict on Arabs after 9/11, two comprehensive studies in which he analysed at least 1150 films (Shaheen 2008, p. XIV). Shaheen (2008, p. XI) argues that Arabs 'remain the most maligned group in the history of Hollywood' and shows how malicious 'stereotypes equating Islam and Arabs with violence have endured for more than a century'. Shaheen (2009, p. 8) also argues that since 1896, the Arab in film has been for the most part 'Public Enemy \# 1 - brutal, heartless, uncivilized religious fanatics and money-mad cultural "others" bent on terrorizing civilized Westerners' and dim-wits who abuse women. Similarly, Edward Said (1994, p. 108) states:

These contemporary Orientalist attitudes flood the press and the popular mind. Arabs, for example, are thought of as camel-riding, terroristic, hook-nosed, venal lechers whose undeserved wealth is an affront to real civilization. Always there lurks the assumption that although the Western consumer belongs to a numerical minority, he is entitled either to own or to expend (or both) the majority of the world resources. Why? Because he, unlike the Oriental, is a true human being. 
These stereotypes, which have been inherited from colonial times if not earlier, persist to this day, and so does the perception of the Arab as not being fully human and undeserving of wealth. The European colonisers have previously engaged in an ambivalent relationship with the East, and specifically with the Arabs, who in some ways were never forgiven for occupying parts of Europe during the Islamic Empire. According to Said (1994, p. 59), Islam remained 'a lasting trauma', and it was only the Arab and Islamic Orient that 'presented Europe with an unresolved challenge on the political, intellectual, and for a time, economic levels' (Said 1994, pp. 73-74). The Ottomans, who were Moslems but not Arab, reinforced this notion when their empire 'lurked alongside Europe' up to the end of the seventeenth century (Said 1994, p. 59). The Arab lands, however, represented a mystery that needed to be unravelled; images from the Arabian Nights populated the psyche of Europeans. Arabian lands juxtaposed images of the veiled, the secretive, the hidden with absolute licentiousness. Moreover, Arabs were seen as a people who valued conflict over peace, were bent on revenge and for whom the end will always justify the means (Said 1994, pp. 48-49). ${ }^{2}$ With these attributes, Arabs can never be 'rational, peaceful, liberal, logical, capable of holding real values' (Said 1994).

The Arabs have rarely been portrayed as normal or average people in Hollywood. It is worth noting that stereotypical representations have also been true of a number of ethnic groups in the past, namely, Native Americans, Italians, Jews, Blacks and others. Yet, stereotypical depictions of most ethnic groups are now taboo and considered politically incorrect and have been replaced by attempts at more faithful and less vicious portrayals. There appears to be an attempt to show other ethnicities in a better light, even though most portrayals still fall within the earlier stereotypes propagated by Hollywood, and representations still are inadvertently measured against what Hollywood perceives as the norm, namely, that which is white, middle class and Christian, preferably Protestant. Overall, with the exception of the depiction of Arabs, cinema has of late tried to show less stereotyped presentations of previously degraded ethnic or minority groups. In Hollywood films, the Arab, however, remains debased, and this is unfortunately accepted as the norm, with the most typical portrayal being that of the terrorist.

In addition, as Carl Boggs and Tom Pollard (2006, p. 335) rightly state:

Terrorism has become a vital source of narratives, fantasies, and myths that contribute so much to highly entertaining cinema, with its international intrigue, exotic settings, graphic violence, and the putative conflict between good and evil. Scenes of terrorist and counterterrorist activity have a natural cinematic appeal, above all in the US where the gun culture, civic violence, crime sprees, and a flourishing war economy permeate the landscape.

The Arab has become the landscape on which all these fantasies are enacted. In the various media and specifically in film, the Arab is essentially presented as the evil other that has to be destroyed. Like Kristeva's abject entity, this other is always outside of what is perceived as civilised; the other is physically threatening and revolting by its actions. This abjection has to be contained. Kristeva (1982, p. 1) argues that within abjection lies a dark and violent revolt at being, which is directed against a threat that 'seems to emanate from an exorbitant outside or inside' and is essentially based on a loss in one's being and a violent mourning for a lost object. The abjection within, which in essence is a product of a loss, is exteriorised onto another. Essentially, a feeling of insecurity within, or resulting from a part within a being that one detests, dictates that an outlet for such feelings should be found. Once exteriorised, a person can feel that these depictions, by becoming external, are no longer part of the self. In Evil Arabs in American Popular Film: Orientalist Fear, 
Tim Jon Semmerling (2006, p. 2) suggests that the evil portrayal of Arabs in American film is possibly 'oblique depictions' of insecure Americans and specifically because Arabs are accepted as fair game. The insecurity is no longer one's own; it now emanates from an outside and is now the object that has to be destroyed.

Karen Engle (2009, p. 107), on the other hand, states: 'US and imperial anxieties about racial purity are transferred onto the body of the terrorist, and the project of giving a name and a face to terror.' The abject functions as a binary opposition; it has to be what the self does not perceive itself to be or opposite of what the self aspires to be. The ugliness is projected onto the other; I am what this other is not. Self-doubt is the primary reason that impels people to extrapolate the abject within on an other that is not perceived fully human. Semmerling (2006) adds that the insecurity that characterised the Americans during the second half of the last century was initially due to a feeling of loss incurred in Vietnam and, at a later stage, by a number of events that followed the Vietnam War. Examples that possibly heightened the sense of anxiety are the oil embargo of the 1970s, the hostage crisis in Iran (although Iran is not an Arab country), ${ }^{3}$ the US marine bombing in Beirut in 1983 and the TWA hijackings in 1985 (Semmerling 2006). According to Semmerling, the latter events led to exaggerated feelings of impotence and humiliation. The Americans, hence, had at once to redeem their image to themselves and to the rest of the world. In such a scenario, a displacement of sorts occurs. An enemy had to be found and the Middle East provided such a place, as this region at times did not play according to the set rules; in other words, the actions of the Arabs did not always respond to American desires, ideologies and myths (Semmerling 2006). Boggs and Pollard (2006, p. 338) add:

By the late 1980s, with the Cold War in its death throes, cinematic terrorism - following a hiatus of nearly two decades - moved onto new ground, turning to the Middle East where Arab/Muslim militants were locked in battle with Israel and, to a lesser extent at the time, the US. These groups replaced Communists and kindred time-honored demons as larger-than-life screen villains.

Furthermore, certain actions by Arabs, such as the hijacking of planes, provided Americans with a scapegoat. In film, the Arab is essentially evil and, being part of the mythical east that Said (1994) has described in Orientalism, has no morals and is fundamentally corrupt without any chance of redemption. The Orient, specifically the Arab world, is a 'living tableau of queerness' in which dwell villains and dubious characters intent on evil (Said 1994, p. 103). At the heart of their being, only darkness lies. This black interior is projected onto the physique of the Arab; the image has to be ugly, dark, sinister and repulsive.

Engle (2009, p. 94) states:

Facialization refers to [ . . a] historical practice of linking surface with depth. More specifically, it refers to the process of making unseen interior truths visible by projecting them onto the surface of the body using the medium of photography. Facialization operates as a method of identification whereby the face of a subject, which is believed to reveal an interior truth, or deep essence, comes to stand for the narratives a nation tells about itself.

The unsightly face of the Arab not only becomes the emblem for all Arabs, irrespective of their calling or cultural background, but also exposes the interior of the self, hence, the abject depiction. Arabs were stereotyped and framed to fit within the trope of the terrorist, manifested by a threatening physical appearance, scornful and vindictive eyes and exaggerated noses; some of the faces at times may have even bordered on the caricature. This representation of the Arab, according to Said (1994, p. 286), was a transference of 
an already present 'anti-Semitic animus'; and it became more evident during and following the oil embargo, in which Arabs were blamed for all evils. The underlying feeling has always been that Arabs should not be in control or even have the right to own a commodity like oil; after all, they are lethargic primitive idiots, who can barely be considered human. According to Boggs and Pollard (2006, p. 338): 'The terrorist enemy was seen as semicivilized, violent, shady, beyond redemption, capable of horrendous crimes - traits making them suitable for extermination.' In the documentary, Reel Bad Arabs (2006), Shaheen adds: 'The Arab is a one dimensional character . . cartoon cut outs used by film makers as stock villains and as comic relief. ${ }^{4}$ One of the examples used to illustrate this point in the documentary is the dialogue that takes place between Xaviera Hollander (Joey Heatherton) and Sheikh Ali (Jerry Fischer) in a restaurant in The Happy Hooker, 1977. In it, she complains about having intercourse with 'circumcised dogs', to which he answers, whilst eating in a revolting manner, that having tried both dogs and sheep, the former are better. ${ }^{5}$ Once again, we are reminded of the undeserving and repulsive oil sheikh who has so much money and spends lavishly without appreciating the value of anything, a raging bull that has no control over its primal instincts, representing the antithesis of what being civilised is. These actions of the perverted sheikh are always juxtaposed against the struggles of the righteous Westerner who has to endure these rising costs of oil.

The terrorists in Delta Force ${ }^{6}$ (1986) and Salim Abu Aziz (Art Malik) in True Lies (1994) also provide excellent examples of the villain's portrayal, ${ }^{7}$ the Arab who is irrational and unable to control his or her anger, always bent on revenge and takes pleasure in killing others. Even the advertising industry has not been spared. Albert Moses, a British national of Sri Lankan descent, has played the role of the Arab in two commercials, in a 1981 episode of Tales of the Unexpected and in The Awakening (1980), even though physically he does not look like an Arab; nonetheless, he was chosen to portray the Arab soldier in the Nescafé commercial, the Arab Sheikh in the Concorde advert, the Arab patrolman in 'Would you believe it' and the Egyptian bandit in The Awakening (1980). ${ }^{8}$ The so-called Nescafé Arab soldier wears Bedouin clothing (see Figure 1), carries a machine gun with a bullet holster and dons large black spectacles obliterating his eyes. He stands nonchalantly and threateningly waving a machine gun. Similarly, the Arab sheikh in the Concorde advert also supports large black spectacles (see Figure 2). In both adverts, and in The Awakening, the character is portrayed as very black, reflective of a very dark soul. The glasses become the barrier that marks the human from the non-human, a soulless non-human or a human being with a soul that cannot be redeemed.

Boggs and Pollard (2006, p. 336) argue that this process of dehumanisation of the Arabs began well before the events of September 11, 2001:

For cinema as for politics the 'Middle East' now exists as a quasi-mystical category largely outside of time and space, a ready source of dark fears and threats. Such ideological bias has shaped public understanding of the region (as well as terrorism) for many years in advance of $9 / 11$, reflected in a new wave of Middle East-centered terrorist films beginning in the early 1980s.

In other words, Arab has become synonymous with terrorist and the site onto which the abject within the self is projected.

In his discussion on colonialism, Homi Bhabha (1994, p. 101) argues that the other can only exist within the fixed framework created by the coloniser. He states: 'in the colonial discourse, that space of the other is always occupied by an idée fixé: despot, heathen, barbarian, chaos, violence'. Once defined as a barbarian heathen in film, the Arab 


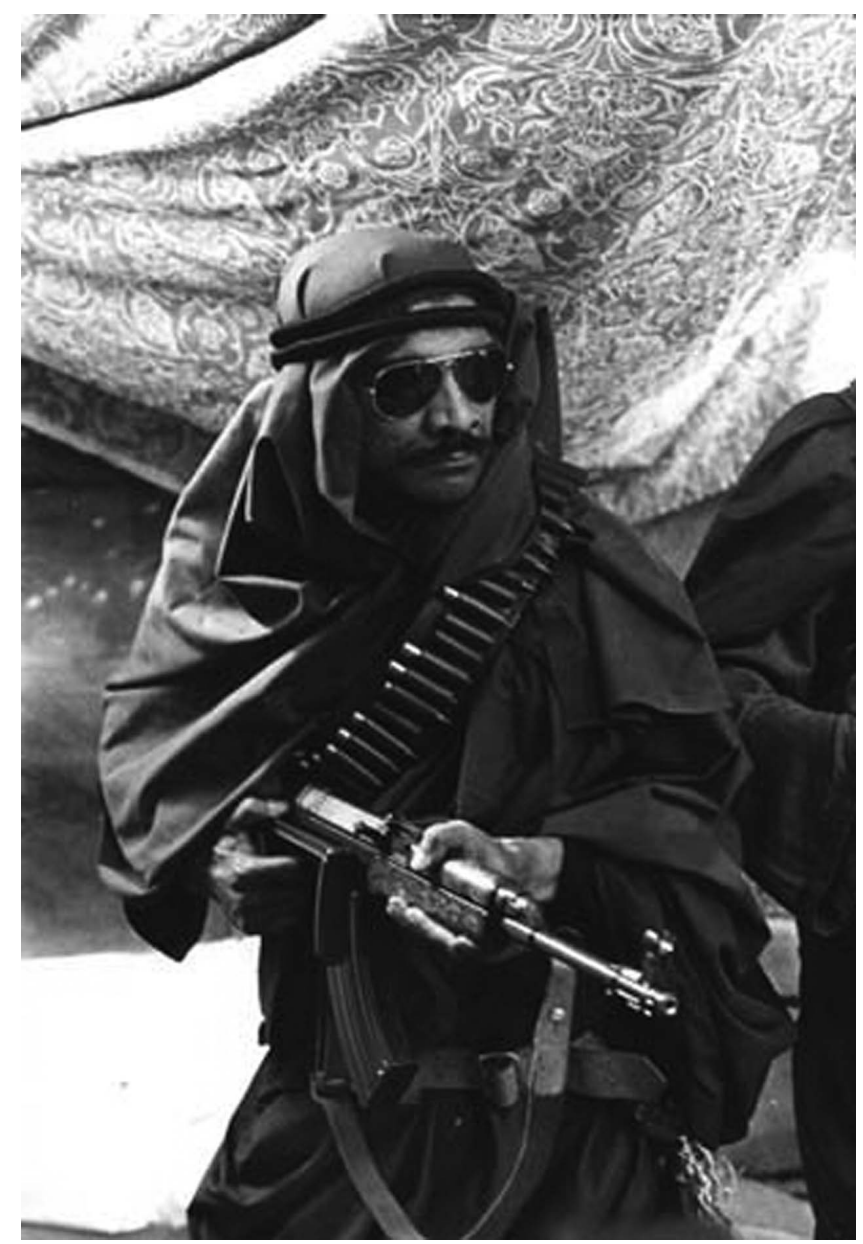

Figure 1. Albert Moses as the Arab soldier in the Nescafé commercial.

is fixed in this role. Failing that, the colonised can only be contained through the stereotype, and according to Semmerling (2006), this redirects attention from the lack within to a fixed outside stereotype. Fear of the Arabs had to be addressed and film provided an ideal venue. Moreover, the fixed image of the terrorist is the predominant stereotype of the Arab. This even extends to Arab-American role casting in Hollywood. Shaheen (2008, p. 58) states:

From the start, Hollywood placed Arab-American actors at the back of the bus. Beginning with early silent films and over a span of 50 years, pioneer performers such as John George from Syria and Frank Lackteen from Lebanon were typecast as reel bad Arabs. In more than 100 films, George and Lackteen were relegated to portraying stereotypical Arab villains: sneaky spies, shifty bargainers, even Nazi sympathizers.

This is the only role the Arab is allowed to play, thus, transferring the abject within the self on an abhorrent stereotype representation of the Arab; if the role is played by an actual Arab, it becomes even more justifiable and the task is much easier. 


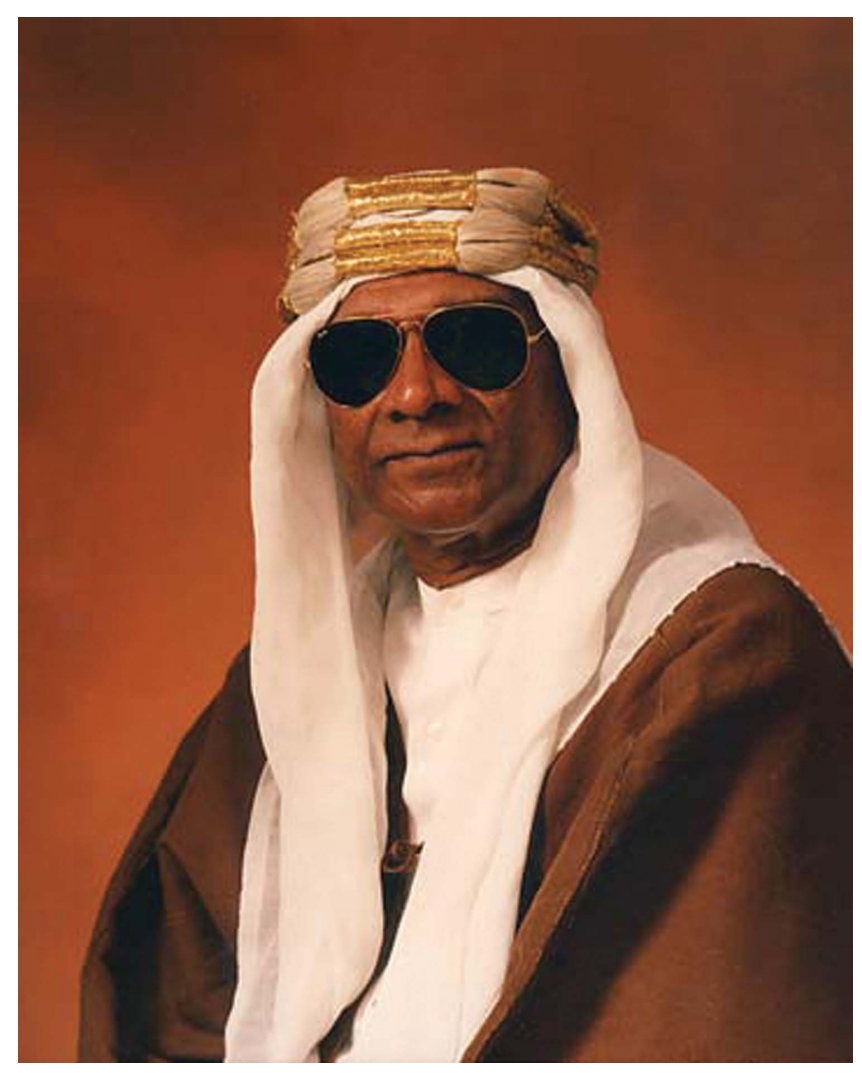

Figure 2. Arab Sheikh in the Concorde commercial.

Through the visual media, we can at once confront the phobia and avenge it by triumphing over its ugly depiction. That other, which is not us, has to be a symbol of what is abject, sinister and dark. This abject entity is at once repulsive and frightening. It is and remains the enemy of any rational civilised being, and it dwells in primitive locales such as scorching deserts that cannot be inhabited by normal human beings. This abject other thrives on killing people for sport; it is usually an over-sexed grotesque-looking sheikh who pursues Western women lecherously as in the example of Jamie Farr in the role of the sheikh in the Cannonball films (1981, 1984), who tells the viewers that he 'has a weakness for blonds and women without moustaches', a statement which also hints at perversion. ${ }^{9}$ According to Khatib (2006), the over-sexed and lustful sheikh, who was equally repulsive, has progressed to become the terrorist of today. This is the only site the Arab is allowed to occupy.

\section{In the beginning were cartoons}

The creation of such an image begins with cartoons, in which the image of the ugly Arab is introduced as a reality onto which the rest of the animation is based. A good example is the opening scene of the Walt Disney animation, Aladdin (1992). ${ }^{10}$ The first scene of the film opens with a man riding a camel in the desert and he tells us that in his home it is customary to cut off the ears of people simply if they don't like them, and this should be accepted as a normal practice, as his homeland is barbaric. 
The original first verse (1992-1993) was later changed by omitting the action of chopping off ears and replacing it with a description of a flat land of scorching heat. ${ }^{11}$

The operative word, however, in both verses is barbaric. Such facts are presented as the truth; no questions on their validity are posed. ${ }^{12}$ This stereotypical presentation of the Arab man prevails in cinema, along with the Arab female who needs to be rescued from the shackles of this man and from a society that can only subjugate her. Shaheen (2009, pp. 28, 29) summarises how the Arab female is portrayed in Hollywood: 'her mute on-screen non-behavior and black-cloaked costume serve to alienate the Arab woman from her international sisters', as 'Arab women ... are [generally] humiliated, demonized, and eroticized' in film. As Arab female representations will not be addressed in this article, it suffices to note that in Hollywood films, they are the non-beings, the black-moving objects - BMO. ${ }^{13}$ A certain image has been defined and engraved in the collective memory of moviegoers since their childhood days; and as the influence of Hollywood extends beyond the United States, and with the impact that film and other forms of media have, the repeated image of the ugly Arab becomes the only possible one.

Toby Miller et al. (2005, pp. 1, 9, 10) state: 'Each year, more movie tickets are sold than there are people on the planet .. . Those audiences are mostly watching fiction conceived, made and owned by Hollywood', and the fact that 'US companies own between $40 \%$ and $90 \%$ of the movies shown in most parts of the world . . . For 2001 and 2002, all the top twenty films in the world were from the US.' Hollywood also dominates the world market by owning distribution rights (Miller et al. 2005, p. 296). According to UNESCO's Institute of Statistics (n.d.), 'In 2006, the United States was the largest film producer in the developed world', with 485 films, even though India has the largest film industry in the world, with 1091 films. Given that the English language has become the lingua franca, Hollywood's influence outweighs India's. Hence, films produced by Hollywood are more pervasive. Therefore, Hollywood's Arab image is the one that prevails.

This image can also affect the way Arabs see themselves and can have a tremendous influence on Arab youth who may begin to see themselves in this light. In his lecture at Ted, Naif al Mutawa (2010), a psychologist who is the creator of the cartoons 99, confirms this. He tells us:

I gave a lecture at the medical school at Kuwait University . . . and I gave the students two articles, one from the New York Times and one from New York magazine. And I took away the name of the writer - everything was gone except the facts. And the first one was about a group called The Party of God, who wanted to ban Valentine's Day. Red was made illegal. Any boys and girls caught flirting would get married off immediately, okay. The second one was about a woman complaining because three minivans with six bearded men pulled up and started interrogating her on the spot for talking to a man who wasn't related to her.

And I asked the students in Kuwait where they thought these incidents took place. The first one, they said Saudi Arabia. There was no debate. The second one, they were actually split between Saudi and Afghanistan. What blew their mind was the first one took place in India; it was the party of a Hindu God. The second one took place in upstate New York. It was an Orthodox Jewish community. But what breaks my heart and what's alarming is that in those two interviews the people around, who were interviewed as well, refer to that behavior as Talibanization. In other words, good Hindus and good Jews don't act this way.

The above is an example of how media influences people's perceptions of themselves. The students have internalised the image of the terrorist and accepted that the terrorist, or in this case, the fundamentalist, which media has successfully reduced to a terrorist (Khatib 2006), could only be one of them. Young Arabs become accepting and somewhat desensitised 
towards the image of the terrorist, specifically because they feel helpless in front of it. The media are insistently telling them that this is who you are. Arena and Arrigo (2006, p. 27) state: 'Personal identity is the feeling of difference from others and social identity is the feeling of similarity to others.' The media is also impressing upon them that they are that abject other and this becomes accepted by them as part of their identity, even if partially. Moreover, Arena and Arrigo (2006, p. 38) add: 'an individual could not develop personal (self-) esteem without a clearly defined personal identity'. A large section of this identity becomes defined by Hollywood films, which have a vast influence on viewers around the world, including Arab viewers. ${ }^{14}$ The latter manifests itself in different ways in the psyche of the individuals; for some, it resides within as the abject that needs to be exteriorised while for others it is the abject within that has to be oppressed. Complete rejection of this image is more difficult to attain, especially given the events that have occurred post-September 11, 2001.

Arena and Arrigo (2006, p. 18) explain how fragile youth with low self-esteem not only succeed in assimilating the traits expounded by films and media, but also begin to enact them:

\begin{abstract}
. . . young people are expected to master the crisis of identity versus role confusion. In this phase, adolescents develop a strong sense of self or become bewildered about who they are and the roles they are to assume in life. Appropriately completing this stage means that one possesses a strong sense of direction and a solid set of core values, leading to a healthy, productive life. However, failing to successfully master the psychosocial dilemma of this period produces personality impairments and leaves the individual in a perpetual 'identity crisis' for the remainder of his or her life. Erikson theorized that young people with little or no sense of self and belonging were especially susceptible to adopting a negative identity such that they were inclined to engage in behavior deemed inappropriate by society. The assumption here was that these youth sought out social disapproval that confirmed their negative identity and, correspondingly, their own limiting self-expectations.
\end{abstract}

In some instances, the youth watched the films and sought out the image of the terrorist. Ahmad Fadeel al-Nazal al-Khalayleh, who was better known as Abu Musab al-Zarqawi, could present us with such an example. ${ }^{15}$ As a youngster, he was involved with numerous incidents with the Jordanian police and often struggled with alcoholism; he was a social misfit, trying to shape his identity outside of the small town of Zarqa (Brisard 2005). Afghanistan and his subsequent association with al Qaeda provided him with an opportunity to reinvent himself. ${ }^{16}$

In Reel Bad Arabs, Shaheen (2008, p. 8.) asks us 'to pause and visualize the reel Arab'; what we see are black beards, dark sunglasses, headdresses and 'usually threateningly exotic or dark-looking' people (Shaheen 2008, p. xii). The dark complexion in this context denotes a disturbing fact. It not only functions as the opposite of white, but also represents the impure. The Manichean principle is at play here; white is the norm/the rational/the pious and this is pitted against black the abnormal/irrational/evil. In film, the Arab, irrespective of the many races the Arabs originate from, is invariably portrayed as dark. In his book, White, Richard Dyer (1997, p. 22) argues that white was viewed as superior to non-white, as it symbolises a pure race which is superior to all others. One of the myths formulating this belief is the link between the inhabitants and the environs in which they dwell; the colder the place the purer the soul. Dyer (1997, p. 21) states that colder climes are characterised by '. . . the clarity and cleanliness of the air . . . the greater nearness to God above and the presence of the whitest thing on earth, snow. All these virtues could be seen to have formed the white character, its energy, enterprise, discipline 
and spiritual elevation, and even the white body'. Given that the Arab lands are usually depicted as stifling deserts, such environs can only produce primitive beings with dark souls.

\section{Enter the real terrorist}

The menacing image of the Arab is the one that has visually accompanied Arab youth in film. In this article, I will not be discussing the religious connotations of the image that most of the terrorists have decided to adopt, as finding support for their dishevelled physiques and outdated apparel is always possible through an anachronistic view of history or quoting religious texts out of context. The image that most of them have decided to adopt is the frightening one that Hollywood has provided for them. In films, they were told that this is the image that is most feared. They played into this fear. Equally, this is the very image they tried to avoid when they executed their terrorist acts on September 11, 2001. Mary Gordon (2001) wrote in the New York Times: 'To have an enemy with no name and therefore no face, or even worse, a name and face that can only be guessed at, is the stuff of nightmare.' The terrorists knew well that the airport security will be looking for Hollywood images of Arab terrorists, so their threatening appearances were forgone on this particular instance. Engle (2009, p. 121) rightly states: 'Terrorism wears a turban [and] smells bad.' But the September 11 terrorists specifically worked against the expected stereotype. In his discussion of fundamentalists, Slavoj Žižek (2008, p. 73) argues that the latter's actions emanate from a fear of inferiority rather than superiority, and from internalising certain standards. He states: 'The problem is not cultural difference (their effort to preserve their identity), but the opposite fact that the fundamentalists are already like us, that secretly they have already internalized our standards and measure themselves by them.' Therefore, working against the perceived type of what an Arab should be is part of this internalisation process. The terrorists are in effect measuring themselves against the standards that have already been set by the media, and specifically film, and are, therefore, capable at playing the needed roles.

However, post the tragic September 11 events, images of the perpetrators began to emerge as more al Qaeda-linked suspects were apprehended. Although the terrorists were never identified as they passed through airport security, as they failed to conform to the expected stereotype, the photos we have seen of them all play into the abject representation of the Arab terrorist. In the photos, which provide us with similar depictions, the representations have adhered to a unified and expected image of the terrorist, the evil image awaited by the viewers. In addition, Arena and Arrigo (2006, p. 301) reflect on the reason behind the terrorists' need to adopt a unified image. They state: 'For example, some individuals appropriate a particular clothing style in order to "look the part". Interpersonal prompts consist of specific actions or mannerisms that one relies on to elicit a response from others, bringing the self-relevant meanings in line with the identity standard.' The fears that have been created through film, namely, since the 1970s, have been realised in September 2001. Since 2001, images of terrorism suspects abound on television screens. What I found striking with these images is the grotesqueness of the person portrayed. Granted, some are criminals, while others are suspected of terrorist acts, but the unifying feature lies with the choice of the photos shown; most of the images portray repulsive and disturbing individuals. ${ }^{17}$

It is worth noting that this was not the case when Timothy McVeigh's photos were earlier shown on various media outlets following his arrest after the Oklahoma bombings in April 1995. McVeigh, who detonated a bomb in front of the Alfred P. Murrah Building 
in Oklahoma City and was responsible for the death of 168 people, was executed on 11 June 2001. In spite of the enormity of his crime, McVeigh was never visually portrayed in a debasing or undignified way. The photos that were circulated of him following his arrest, sentencing, conviction and even prior to his execution never demeaned him. A number of his photos, which were used by various media outlets, were Associated Press photos; in all of them, McVeigh appeared to be very presentable. ${ }^{18}$ In one photo, in which he is seen being escorted from the courtroom, he is clean-shaven, and if it were not for the orange prison jumpsuit, one could have easily mistaken him for an American marine.

The practice of maintaining the dignity of the guilty was not upheld, however, when we saw the photos of the Arab terrorists. Good examples are the Associated Press photos that were circulated of Khalid Sheikh Mohammed, the alleged mastermind of the September 11 attacks, supposedly taken in 2009 and 2003. In the one taken in 2009, Mohammed's image conforms exactly to what we expect a terrorist to look like. According to Wikipedia: 'This image of Khalid Sheikh Mohammed was taken in July 2009 under an agreement with Guantanamo prison camp staff that lets delegates of the International Committee of the Red Cross photograph detainees and send photos to family members' (Worthington 2009). Supporting an Arab red headdress with what appears to be a white sheet cover, Mohammed's hawk-like eyes are staring threateningly and directly at the camera, and his unruly beard only adds to this frightening physique. He looks exactly as we expect a terrorist to look.

His other image, which we also saw endlessly in media, was taken in 2003 and reveals a less threatening man. In it, he is dishevelled, his eyes barely focused, giving him an air of madness. He is in his undershirt, which exposes a very hairy body. In this instance, the animal-like being has been vanquished. However, once he has been cleaned up in Guantanamo, the terrorist emerges. Both of these abject images in some way reflect the hideousness of the act itself and represent the other that has to be destroyed. Khatib (2006, pp. 165-166) argues that the notion of Arab has become synonymous with 'Islamic fundamentalism in contemporary Western culture, from movies to news to social theory' and that 'Islamic fundamentalists have been reduced to terrorists, and therefore dehumanized'. Even though the terrorists are guilty and deserving of punishment, the images that are shown of them are humiliating. Alleged criminals appearing in courts, for instance, are usually well dressed and this grants them some dignity. The terrorists, however, wore their criminality on their faces. As we have seen these faces before, seeing these images on the various news networks did not come as a surprise. Moreover, and as with film, this abject image of them which emphasises their otherness can only add to this process of dehumanising the Arab. The terrorists' images were but an extension of a process that has begun with film.

In his study of the Nazi camps, Giorgio Agamben (2002, p. 44) tells us that the inmates were never referred to as people by the guards; instead, they were given degrading names, justifying making them the site for various experiments; they were no longer human beings, but entities that occupy the space between the human and the non-human. Agamben states: 'The living dead there were termed donkeys; in Dachau they were cretins, in Stutthof cripples, in Mauthausen swimmers, in Neuengamme camels, in Buchenwald tired sheikhs, and in the women's camp known as Ravensbruck, Muselweiber (female Muslims) or trinkets.' Agamben (2002, p. 52) adds: 'Before being a death camp, Auschwitz is the site of an experiment that remains unthought today, an experiment beyond life and death in which the Jew is transformed into a Muselmann and the human being into a non-human.' The Jews in the camps were never referred to as humans; this process of dehumanisation opens the doors to all forms of mistreatment. They have been reduced to homo sacer, banned 
and abandoned by the law, 'exposed and threatened on the threshold in which life and law, outside and inside, become indistinguishable' (Agamben 1998, p. 28).

In Hollywood movies, such naming is also used when referring to Arabs. Shaheen (2009, p. 17) states:

Hundreds of movies reveal Western protagonists spewing out unrelenting barrages of contested slurs, calling Arabs: 'assholes', 'bastards', 'camel-dicks', 'pigs', 'devil-worshippers', 'jackals', 'rats', 'rag-heads', 'towel-heads', 'scum-buckets', 'sons-of-dogs', 'buzzards of the jungle', 'sons-of-whores', 'sons-of-unnamed goats', and 'sons-of-the-she camels'.

Once you deem a certain race or ethnic group not fully human, all inhibitions fall, and all actions become permissible, including representations of them. Torture such as we had seen in Abu Ghreib and in Guantanamo is made possible by this process of dehumanisation, as well as the recent wars on Afghanistan and Iraq. Film has prepared people to accept them, as reel 'shoot-em-ups like True Lies and Rules of Engagement, which depict gungho Americans gunning down vicious Arabs, help pump today's [US] troops up' (Shaheen 2008, p. 21). Shaheen (2008, pp. XVIII, XXII) also argues:

Filmmaking is political ... Dehumanizing stereotypes emerging from the cinema, TV, and other media help support government policies, enabling producers to more easily advance and solidify stereotypes . . . In turn, the stereotypes influence policies. During times of conflict, especially, media systems function as common carriers for government policies.

Moreover, on a number of occasions, senior White House advisors and US government officials were invited to private screening of films by the Motion Picture Association of America (Shaheen 2008, p. XXII). ${ }^{19}$ Not only is the contributory role of entertainment to government discussed, but also how villains can be created through film to aid certain future actions. If Arabs are portrayed as criminals then any deed against them becomes justified.

The images to which we were exposed of the Arabs, and later of the terrorists, are in some ways akin to a process of dehumanisation of an ethnicity. The terrorists' photos had to fit in the mould that had previously been defined by film. Erving Goffman (1974, p. 11) wrote that a frame is a 'principle of organization which governs events - at least social ones - and our subjective involvement in them'. According to Goffman (1974, p. 21), we use frames in order to 'locate, perceive, identify, and label' occurrences surrounding us. Moreover, 'the very significant assumption is generally made that all events - without exception - can be contained and managed within the conventional system of beliefs' (Goffman 1974, p. 30). Hence, the image of the terrorist had to fit in the previously assigned frame. Stereotyping people is in itself a form of framing; if an individual confirms to what the stereotype dictates, then people are more at ease. When the terrorists' images started flooding the TV screens, the lesson that was initially given to children with cartoons, which according to Shaheen $(2008$, p. xi) is the equation of 'Arab $=$ Muslim $=$ Godless Enemy', is consolidated for adults, as reel images are now viewed 'against a montage of real-life images'.

\section{Uncanny productions}

At least two films, which were produced prior to September 11, 2001, uncannily have plots or scenes that mirror actual events, which they preceded. In the opening scenes of The Siege (1998), we see what appears to be a terrorist in the form of an elderly bearded Saudi Sheikh sitting at the back of a Mercedes car, as it manoeuvres its way through 
the desert with the mandatory camels in the landscape, heading towards a village. ${ }^{20}$ At the entrance of the village the car is surrounded by goats; then the driver is killed, and the suspected terrorist is abducted by American Intelligence forces. The terrorist's name, we learn, is Ahmed bin Talal, a family name suggestive of that of a real Saudi prince. ${ }^{21}$ The beard and the attire mirror those of the late Osama Bin Laden, whose al Qaeda group has been linked to a number of terrorist attacks around the world, including the September 11 attacks. The tagline of the film states 'Our freedom is history', and during the press conferences leading to the attack on Afghanistan, President George W. Bush told the American people: 'Tonight we are a country awakened to danger and called to defend freedom', and the actual operation is called 'Enduring Freedom'. Attorney General Ashcroft described the September 11 attacks as an 'assault on America and its freedom'. The repetition of the word freedom uncannily resonates with the tagline in The Siege, which states 'Freedom is history'. An Arab-American detainee who was rounded up after September 11 remarked that the experience felt like he was actually part of a movie (Shaheen 2008, p. 21).

In a scene from an earlier film, The Long Kiss Goodnight (1996), an event similar to September 11, 2001, is discussed. ${ }^{22}$ A dialogue between Leland Perkins (Patrick Malahide), Samantha Caine/Charly Baltimore (Geena Davis) and Mitch Henessey (Samuel L. Jackson) describes how the CIA could pave 'the way to a bombing to justify a budget increase' and blame the event on Moslems. Is it conceivable that these plots have given ideas to the real terrorists? Are the real terrorists playing into that fear that has been instilled in Americans throughout the years? After all, is this not the only true depiction of the Arab?

\section{Which came first: the real or the reel?}

When the terrorists were caught, we were subjected to film footage of their images endlessly on various platforms of the news media. The images that were shown depicted them exactly as we expected: evil threatening eyes staring from behind various face and head covers, or defeated and humiliated individuals who looked barely human. ${ }^{23}$ These noxious images of the terrorists, repeated ad nauseam on the television screens, affirm the fact that this is the only Arab out there. We have seen the unshaven beards, dishevelled hair, the bloodshot eyes, the hooked noses and the strange turbans before. Nadine Naber (2008, p. 26) argues, '. . . religion coupled with civilizational discourses support the construction of "the Arab" as different from and inferior to white Americans' who needs to be vanquished by a superior power. We had seen them in chains, defeated and completely dehumanised before. No question about whether they are guilty; they fit the part and as in films, they have been humiliated and defeated; Abu Ghreib and Guantanamo have provided us with ample footage of humiliated and disgraced individuals. Showing the terrorists in such forms takes away their humanity. Once again, a question poses itself: Could the terrorists be playing into the image that has been created for them? The phobia that has been nurtured in Hollywood has become a reality. Furthermore, is it not possible that the terrorists constructed their images to fit within the framework that has previously been created? Is the image of the terrorist a construct to play against America's worst fear?

Engle (2009, p. 97) states:

Twenty-one of the twenty-two men on the FBI list hail from various countries in Africa and the Middle East. When complexion is noted on these rap sheets, it is alternately olive, dark, or black . . . 12 in this sense, the FBI list operates as a template for 'proper' terrorist identification: nonwhite, non-English-speaking, usually non-American, and always male. 
Even though on rare occasions the terrorist in film was a female Arab, the predominant character is male and matches the above description. ${ }^{24}$ The FBI's terrorist list published faces that corresponded with the reel image of the Arab. However, these are the same characters who managed to get through security without being caught. As Hollywood has long dictated what an Arab terrorist should look like, the hijackers cleaned up their image to escape profiling. At that time, they did not assume the image of the reel Arab terrorists. Engle (2009) argues that even when John Walker Lindh, who was not even Arab, was captured, the images that were published of him had to adhere to the same formula of the representation of the reel Arab. ${ }^{25}$ Engle (2009, p. 100) adds:

In photographs published of Lindh following his capture, the generic conventions of racial typing are unmistakable ... Looking alternately psychotic, dirty, and dark-skinned, the transformation of a white American into an unclean Eastern savage is near perfect. Lindh is pictured not simply as deranged and foreign but also as a neutralized threat. The images of Lindh in captivity emphasize his impotence as they establish his Otherness.

Engle (2009, p. 100) then draws a comparison between Lindh's photographs and the footage we were endlessly subjected to of the capture of the previous Iraqi dictator, Saddam Hussein. She writes:

How similar the Lindh photographs are to those images of the captured Saddam Hussein we saw in 2003. Dishevelled, dirty, and publicly subjected to the authority of medical examiners, Hussein was stripped of his former authority and exposed to humiliating treatment.

The arrest of the previous Iraqi dictator had to be enacted on television screens according to the previous formulae. The defeated terrorist climbs out of a filthy hole in the ground, completely defeated, like a beast, too dirty to be touched by bare hands; his unruly sight is no longer threatening. This image of the Iraqi dictator brings to mind the 2003 photograph of Khalid Sheikh Mohammed.

Additionally, the terrorism sites on the Internet depicting masked men threatening America, speaking an antiquated form of Arabic, play into this repertoire of this abject image. Are they in fact mirroring the image of the reel Arab? The boundaries of what came first are now blurred: the image or the terrorist? Are we witnessing, as Baudrillard (2004) would have described it, a simulation of the real? Baudrillard (2004, p. 1) discusses Borges' fable in which 'the cartographers of the Empire draw up a map so detailed that it ends up covering the territory exactly'. Eventually, this map becomes the 'most beautiful allegory of simulation', and the map eventually precedes the territory. If one needs to revisit the territory, one can do so through consulting the map. Hence, the original is lost in this process of simulation; we are no longer able to distinguish the real from the virtual real. Similarly, this blurring of reel and the real terrorist is rather disturbing. The more images we see on our television screens of the terrorists emulating film images of the reel terrorist, the stronger the blurring. In addition, Hollywood's continual depiction of the ugly Arab continues to exasperate an already fragile situation. The fine lines that exist between the real and the unreal have been eroded. The news media has only consolidated the image.

On 12 March 2006, American soldier, Steven Dale Green, and three others, stormed into the home of 14-year-old Abeer Al Janabi in a village near Yusufiyah in Iraq, shot her family, and gang-raped Abeer, before killing her and setting her body on fire (Sengupta 2010). In an interview with the Washington Post, Green said he went to Iraq to kill people (Sengupta 2010). Green also added: 'it's something I had been through a million times, in 
training for raiding houses. It was just eliminating targets', and according to him, in Iraq 'killing people is like squashing an ant' (Sengupta 2010). People are not people in Iraq, but abject others worthy of being killed. The war, undoubtedly, had a negative impact on Green, but the actions mimic film scenes and even video games; these Arabs are worthy of being killed. This is confirmed by Shaheen $(2009$, p. 21) when he described how audiences applauded the killing of 83 Yemeni men, women and children at the end of the film Rules of Engagement (2000):

During the scene, viewers rose to their feet, clapped and cheered. Boasts director Friedkin, 'I've seen audiences stand up and applaud the film throughout the United States'. Some viewers applaud Marines gunning down Arabs in war dramas not necessarily because of cultural insensitivity, but because for more than 100 years Hollywood has singled out the Arab as our enemy.

The reel or the real Arab has been defeated through death.

\section{Conclusion: it continues, unabated}

In a new video game called The Line, the same fears and tropes are at play $(2 \mathrm{~K}$ Games 2010). 2K Games, the publisher of The Line, advertises it as 'a provocative, cinematic third-person military shooter that challenges players' own morality by putting them in the middle of unspeakable depravity where brutal life-or-death choices take them on a journey into the heart of darkness' [an evocation of Joseph Conrad's novel Heart of Darkness] and the 'emotional narrative [of the game] unfolds within the destroyed opulence of Dubai (2K Games 2010). Once a playground for the world's wealthiest elite, Dubai has now been reclaimed by Mother Nature, buried underneath the most devastating sandstorm ever recorded' (2K Games 2010). Moreover, The Line 'allows gamers to play as Captain Martin Walker, leader of an elite Delta Force team ordered to infiltrate the treacherous region and bring home US Army Colonel John Konrad [again a direct reference to Joseph Conrad, the writer] (2K Games 2010). Heightening the narrative to a fever-pitch are ultra-realistic operations against enemies who are unafraid of death and hell bent on destruction' (2K Games 2010). The same tropes are introduced. This game is scheduled for release in 2011.

The image of the evil Arab pervades, superseding all others. When we finally saw the faces of the terrorists, we were more than prepared. In conclusion, I would like to end with a quotation from CNN's film America Remembers (2002), which is a fictionalised account of the events of September 11, 2001. The anchor, Paula Zahn, states: 'We finally saw the faces of evil'; evil wears an Arab face. This was confirmed by the Arab faces of the perpetrators, which conformed to the image of the reel Arab. ${ }^{26}$ The reel Arab has finally stepped out of film into real life. The reel Arab has been given the seal of authenticity.

\section{Notes}

1. I am borrowing the term reel from Jack Shaheen's book Reel Bad Arabs.

2. In an article entitled " $B$ lossoming" of democracy in Syria will be long, deadly', Sir Andrew Green, a former British ambassador to Syria, refers to Arab cultures as 'revenge cultures' (Green 2011).

3. As Iran is geographically located in the Middle East, many people assume that it is part of the Arab world. However, Iranians in general are not viewed in the same way as Arabs are viewed. Some Europeans consider them Indo-Arian, and hence, non-Semitics like the Arabs, and therefore superior. In the film Syriana (2005), for example, Arab and Persian lands are 
presented as two opposing worlds, civilised and uncivilised. In the opening scenes of the film, the Arab land is depicted as a scorching desert occupied by Asian workers, which is juxtaposed against the Iranian capital, Tehran, which is a metropolis with ordinary people, doing ordinary things. A line by the US CIA chair to Bob Barnes (George Clooney) in a later scene confirms this vision: 'Iran is a natural cultural ally of the US. Persians do not want to roll back the clock to the 8th century' (Syriana 2005). The implication is that Arabs want to roll back to the eighth century. The problem here lies with the generalisations and stereotypes of Arabs and their lands; some religious groups would like to turn back the clock, and the Arab Gulf countries are home to a large number of Asian workers, but this is not the only reality.

4. Reel Bad Arabs: How Hollywood Vilifies a People, 2006. Film. Directed by Jeremy Earp and Sut Jhally.

5. The Happy Hooker Goes to Washington, 1977. Film. Directed by William A. Levey.

6. The Delta Force, 1986. Film. Directed by Menahem Golan, Director. The trailer can be watched on The Internet Movie Database at: http://www.imdb.com/video/screenplay/vi228918553/.

7. True Lies, 1994. Film. Directed by James Cameron. An image of Art Malik's role as the terrorist can be accessed at: http://www.monstersandcritics.de/downloads/downloads/articles3/144425/ article_images/image5_1246643625.jpg.

8. For the photos, please refer to his official website at: http://www.albertmoses.com/sheikh.htm. For the Arab soldier in the Nescafé advert, see: http://www.albertmoses.com/index.html.

9. For photos of Jamie Farr in the role of the Arab sheikh, please refer to this site: http://www. cinema.de/stars/star/jamie-farr,1545563,ApplicationStar.html.

10. Aladdin, 1992. Animation. Directed by Ron Clements. According to the Internet site, Box Office Mojo, the film grossed around \$504 million worldwide, of which 217 million were in the United States.

11. Lyrics of both versions are available at: http://www.fpx.de/fp/Disney/Lyrics/Aladdin.html.

12. Shaheen discusses some other cartoons that have portrayed Arabs in a bad light. He states: 'Even animated cartoon characters thump Arabs. My childhood hero, Bugs bunny, clobbers nasty Arabs in 1001 Rabbit Tales (1982). Bugs trounces an ugly genie, a dense sheikh, and the ruler's spoiled son. My other cartoon here, Popeye, also trounces Arabs. In the early 1930s, Fleischer Studios' lengthy Popeye cartoons presented Arab folk heroes as rogues, not as champions' (Shaheen 2009, pp. 26-27).

13. This term, or BMO, was used during the 1990 Gulf War by American military when referring to Saudi women wearing the traditional abaya.

14. MBC or Middle East Broadcasting Center group, which is based in Dubai Media City, transmits 10 free-to-air television channels, at least 5 of which carry 24-hour American programming. $\mathrm{MBC}$ is one of the most watched satellite channels in the Arab world, and it transmits via Arabsat and Nilesat. Nearly all Arab countries have an English language dedicated channel, such as 'The One', transmitted by Dubai Media Incorporated, or at least allocates hours to English transmission, which is mainly dedicated to American programmes. Cable networks such as Showtime Arabia also rely heavily on American produced programmes.

15. Zarqawi was born on 30 October 1966, in Zarka, Jordan, and died on 7 June 2006, near the city of Baquba in Iraq, in an American air strike.

16. Terrestrial Television transmission began in Jordan in 1968. In 1972, Jordan television became the first station in the Arab World to transmit foreign programmes in English, French and Hebrew, as it launched Channel 2. According to Arab Media Outlook, Jordan had a 95\% total TV penetration in 2009. The average Jordanian family has been exposed to American films and programmes whether through television or cinema for at least four decades; it is very likely that Zarqawi was as well.

17. For examples of the photos of Khalid Sheikh Mohammed that were repeated endlessly on the TV screens, please refer to: http://www.foxnews.com/story/0,2933,258817,00.html; and http://thelede.blogs.nytimes.com/2009/09/09/photographs-of-khalid-shaikh-mohammed-atguantanamo-appear-online/.

18. An example of one of McVeigh's photos can be found on the BBC website: http://news.bbc. co.uk/2/hi/science/nature/1270956.stm. Another example can be seen at: http://www.trutv.com/ library/crime/serial_killers/notorious/mcveigh/dawning_1.html.

19. MPAA chief, Jack Valenti, and his team, 'Hollywood 9/11 Coalition', held meetings to aid Bush with his war on terror (Shaheen 2008, p. 18). 
20. The Siege, 1998. Film. Directed by Edward Zwick. The photo of Ahmed Ben Larby who plays the role of the Arab sheikh can be accessed at: http://c.mymovies.dk/View.aspx?device=\& guidTitle $=1 \mathrm{~d} 1 \mathrm{f} 94 \mathrm{~d} 9$-dbe6-4588-a3fc-4adcbb5b656e\&guidUser $=\mathrm{d} 8 \mathrm{e} 67 \mathrm{a} 2 \mathrm{c}-\mathrm{a} 3 \mathrm{ee}-492 \mathrm{f}-\mathrm{a} 109-1$ e3f539b418e\&dpi=108.

21. Prince Al Waleed bin Talal is a member of the House of Saud, an international investor and is nephew to the current Saudi Arabian monarch.

22. The Long Kiss Goodnight, 1996. Film. Directed by Renny Harlin. To watch the clip of this

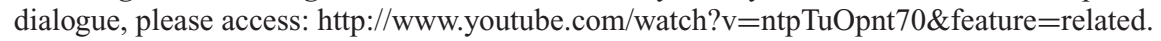

23. The AP photo of Khalid Sheikh Mohammed is a good example. It can be viewed at: $\mathrm{http} / / /$ www.guardian.co.uk/world/2009/nov/13/911-mastermind-trial-challenges-analysis. This photo has been aired on nearly all major TV satellite stations in the world.

24. For a list of the Arab female terrorists in film, please refer to: www.waccglobal.org.

25. Please refer to the BBC site for an image of Lindh; this is the photo that is used for his profile: http://news.bbc.co.uk/2/hi/americas/1779455.stm. In an AP photo, which is taken from TV footage of Mazar-i-Sharif, Afghanistan, on 1 December 2001, Lindh could easily pass for an Arab. His skin appears dark and blotched by soot; his hair is dirty and dishevelled; next to him stands another man equally unkempt.

26. CNN Tribute: America Remembers, 2002.

\section{References}

2K Games. The Line [online]. Available from: http://www.2kgames.com/\#/games/spec-ops-the-line [Accessed 31 December 2010]. DVD version to be released January 2012.

Agamben, G., 1998. Homo sacer: sovereign power and bare life. Trans. D. Heller-Roazan. Stanford, CA: Stanford University Press.

Agamben, G., 2002. Remnants of Auschwitz: the witness and the archive. Trans. D. Heller-Roazen. New York: Zone Books.

Aladdin, 1992. Film. Directed and produced by Ron Clements.

Arena, M. and Arrigo, B., 2006. Terrorist identity: explaining the terrorist threat. New York: NYU Press.

Baudrillard, J., 2004. Simulacra and simulation. Trans. S.F. Glaser. Ann Arbor: University of Michigan Press.

Bhabha, H., 1994. The location of culture. London: Routledge.

Boggs, C. and Pollard, T., 2006. Hollywood and the spectacle of terrorism. New Political Science, 28 (3), 335-351.

Brisard, J., 2005. Zarqawi: the new face of Al-Qaeda. Cambridge: Polity.

Cannonball Run I \& II, 1981, 1984. Film. Directed by Hal Needham. Produced by Raymond Chow.

CNN Tribute: America Remembers, 2002.

Dyer, R., 1997. White. London: Routledge.

Engle, K., 2009. Seeing ghosts: 9/11 and the visual imagination. Montreal, QC: Queen's University Press.

Goffman, E., 1974. Frame analysis: an essay on the organization of experience. New York: Harper \& Row.

Gordon, M., 2001. The fragile city; 'There were no sounds of lamentation' [online]. 25 February 2001. Available from: http://www.nytimes.com/2001/09/16/nyregion/the-fragile-citythere-were-no-sounds-of-lamentation.html [Accessed 28 August 2011].

Green, A., 2011. 'Blossoming' of democracy in Syria will be long, deadly [online]. 28 February 2011. Available from: http://gulfnews.com/opinions/columnists/blossoming-of-democracy-insyria-will-be-long-deadly-1.857601 [Accessed 26 August 2011].

Khatib, L., 2006. Filming the modern Middle East: politics in the cinemas of Hollywood and the Arab world. London: I.B. Tauris \& Co. Ltd.

Kristeva, J., 1982. Powers of horror: an essay on abjection. Trans. L.S. Roudiez. New York: Columbia University Press.

Miller, T., et al., 2005. Global Hollywood 2. London: British Film Institute.

Mutawa, N., 2010. Ted: ideas worth spreading [online]. July 2010. Available from: http://www.ted.com/talks/naif_al_mutawa_superheroes_inspired_by_islam.html [Accessed 25 June 2011]. 
Naber, N., 2008. Introduction. In: N. Naber and A. Jamal, eds. Race and Arab Americans before and after 9/11: from invisible citizens to visible subjects. Syracuse, NY: Syracuse University, pp. $1-45$.

Rules of Engagement, 2000. Film. Directed by William Friedkin. Produced by Scott Rudin.

Said, E., 1994. Orientalism. New York: Vintage Books.

Semmerling, T., 2006. 'Evil' Arabs in American popular film: Orientalist fear. Austin: University of Texas Press.

Sengupta, C., 2010. When soldiers become killers [online]. 6 August 2010. Available from: http://gulfnews.com/news/region/iraq/when-soldiers-become-killers-1.663394 [Accessed 5 August 2010].

Shaheen, J., 2008. Hollywood's verdict on Arabs after 9/11. Northampton, MA: Olive Branch Press.

Shaheen, J., 2009. Reel bad Arabs: how Hollywood vilifies a people. Northampton, MA: Olive Branch Press.

Syriana, 2005. Film. Directed by Stephen Gaghan. Produced by Sarah Bradshaw.

The Delta Force, 1986. Directed by Menahem Golan. Produced by Yoram Globus.

The Long Kiss Goodnight, 1996. Film. Directed by Renny Harlin. Produced by Stephanie Austin.

The Siege, 1998. Film. Directed by Edward Zwick. Produced by Robin Budd.

True Lies, 1994. Film. Directed by James Cameron. Produced by Stephanie Austin.

UNESCO, Institute for Statistics, n.d. Analysis of the UIS International Survey on Feature Film Statistics [online]. Available from: http://sharepoint.uis.unesco.org/culture/ Documents/Infosheet_No1_cinema_EN.pdf [Accessed 22 August 2011].

Worthington, A., 2009. Torture and futility: is this the end of military commissions at Guantanamo? 29 September 2009. Available from: http://pubrecord.org/law/5611/torture-futility-militarycommissions/ [Accessed 10 July 2011].

Žižek, S., 2008. Violence: six sideways reflections. New York: Picador. 